\title{
Selection of Elite Broad Leaf Mustard (Brassica juncea var. rugosa) (L.) Czern. Genotypes in the Mid-hill Condition of Dailekh District, Nepal
}

\author{
Basant Chalise', Tul Bahadur Pun ${ }^{2}$ and Surendra Lal Shrestha ${ }^{3}$ \\ ${ }^{1}$ Horticultural Research Station, Rajikot, Jumla. \\ ${ }^{2}$ Regional Agricultural Research Station, Lumle, Kaski \\ ${ }^{3}$ Horticulture Research Division, Khumaltar, Lalitpur \\ Corresponding author's email: basantchalise@gmail.com
}

Received on: 16 July 2019, Revised on: 10 November 2019, Accepted on: 5 December 2019

\begin{abstract}
An experiment was carried out on six genotypes of Broad Leaf Mustard (Brassica juncea var. rugosa) (L.) Czern. namely 'HRDBLM-001', 'HRDBLM-003', 'HRDBLM-005', 'HRDBLM-007', 'Marpha Broad Leaf' and 'Khumal Broad Leaf' at Horticultural Research Station, Kimugaun, Dailekh, during two consecutive years 2013 and 2014 to identify promising genotypes collected from different parts of Nepal under the Coordinated Varietal Trial (CVT). The experiment was laid out in Randomized Complete Block Design (RCBD) consisting of four replications per treatment. The result revealed that among the six genotypes tested 'HRDBLM-005' (39.78 mt/ha), 'HRDBLM-007' (34.96 mt/ha) and 'HRDBLM-001' (32.36 mt/ha) were found superior
\end{abstract}

Keywords: : Broad Leaf mustard, Coordinated Varietal Trial, Leaf weight, Leaf yield, Organoleptic test

\section{Introduction}

Broad Leaf Mustard [(Brassica juncea var. rugosa) (L.) Czern., 2n=36], commonly known as Brown mustard or Chinese mustard or Indian mustard or Leaf mustard or Oriental mustard or Vegetable mustard is an important leafy vegetable and is widely cultivated from Terai to the mountainous regions of Nepal. It is popular among the consumers because it is cheaper source of fiber, minerals and vitamins. The popularity of Broad Leaf Mustard (BLM) also could be due to its easy cultivation, low production risk and versatile uses (Khatiwada, 2008). The strong pungent taste of BLM is highly preferred by most of the consumers. It is grown in winter season in tropical and sub-tropical regions; however, in temperate region it is cultivated as summer season crop. It is quite tolerant to frost at seedling stage (Dhillon and Larsson, 1985).
A wide variation is found among the cultivars of BLM cultivated in Nepal. The variation is found mostly in spreading, leaf color, leaf surface, presence or absence of trichomes, leaf size (length and width), leaf petiole size, taste of leaf etc. Similarly, variation in growing season i.e. early and mid-season growing varieties are also available in Nepal. Moreover, some varieties are suitable for lower altitude. Paudel et al. (2016) reported that 58 different accessions of BLM have been characterized and evaluated in National Agriculture Genetic Resource Center (NAGRC), Khumaltar, Lalitpur, Nepal.

In one hand, there is higher variation among the available genotypes but on the other hand there are limited alternatives of released varieties with desirable quality for cultivation. 'Khumal Broad Leaf', 'Khumal Red Leaf', 'Marpha Broad Leaf' and 'Tankhuwa Rayo' are released varieties of BLM which have been cultivated since long time (CPDD, 2014). Besides these varieties,

Copyright (C) 2020 Nepal Horticulture Society. This article is licensed under Creative Commons Attribution 4.0 International License. This permits unrestricted use, distribution and reproduction in any medium provided the original work is properly cited. 
some other varieties have also been grown at different regions of Nepal. These are superior to the released varieties based on leaf quality and leaf yield. Therefore, this study was designed to evaluate the performance of different genotypes including some already released BLM varieties for the purpose of registration and release.

\section{Materials and Methods}

The study was carried out at Horticultural Research Station, Kimugaun, Dailekh located at 1,350 m altitude from the mean sea level, during two consecutive years 2013 and 2014. The experimental field was laid out in Randomized Complete Block Design (RCBD) with four replications per treatment. Six genotypes of BLM viz. 'HRDBLM-001', 'HRDBLM-003', 'HRDBLM-005', 'HRDBLM-007', 'Marpha Broad Leaf' and 'Khumal Broad Leaf' were allotted randomly in different plots within the replication. Seeds were sown in nursery bed on $12^{\text {th }}$ September and 25 days old seedlings were transplanted in $2.70 \mathrm{~m}^{2}$ experimental plot at $45 \times 30 \mathrm{~cm}$ spacing containing 20 plants per plot. Fertilizers and manure were applied at the rate of 200:180:80 kg NPK/ ha and $20 \mathrm{mt} /$ ha respectively. Whole dose of phosphorus and potassium was applied as basal while $1 / 3$ nitrogenous fertilizer was applied at basal, 1/3 top-dressed at 25 days and remaining $1 / 3$ top-dressed at 45 days of transplanting. Irrigation was given at weekly intervals and weeding was done fortnightly. Plant was protected from insect pest by hand picking. For sampling, six plants were selected from the inner side of the plot excluding the boarder plants. Multiple harvesting of the leaves was done after one month of transplanting. Leaf quality was determined based on 9-point hedonic scale (Peryam and Girardot, 1952; Peryam and Pilgrim, 1957). Observed data were analyzed using MS-Excel (Microsoft Excel.2010) and MSTAT-C package (Version 1.3). Means were separated with Duncan's Multiple Range Test (DMRT) at 5\% level of significance (Gomez and Gomez, 1984).

\section{Results and Discussion}

\section{Number of leaves per plant}

The Number of leaves per plant showed statistically significant difference in both the years. For the first year, statistically the highest Number of leaf was produced by 'HRDBLM-005' (29.70) and was statistically at par with 'HRDBLM-007' (24.43). The lowest Number was

The Plant spreading was non-significantly varied from $48.37 \mathrm{~cm}$ in 'HRDBLM-003' to $52.37 \mathrm{~cm}$ in 'Khumal Broad Leaf' with mean value $50.94 \mathrm{~cm}$ in the first year. In the second year, the spreading was highly significant and the highest spreading was recorded in 'HRDBLM-007' (48.72 cm) followed by 'Marpha Broad Leaf' (43.45 cm) and the lowest spreading was observed in 'HRDBLM-003' $(38.48 \mathrm{~cm})$. The average data of two years nonsignificantly varied from 50.46 in 'HRDBLM-007' to $43.42 \mathrm{~cm}$ in 'HRDBLM-003' (Table 1).

\begin{tabular}{|c|c|c|c|c|c|c|}
\hline \multirow{2}{*}{ Treatments } & \multicolumn{3}{|c|}{ Number of leaves/plant } & \multicolumn{3}{|c|}{ Plant spread (cm) } \\
\hline & 2013 & 2014 & Average & 2013 & 2014 & Average \\
\hline HRDBLM-001 & $19.63 \mathrm{bc}$ & $18.92 b$ & $19.27 b$ & 50.40 & $41.07 \mathrm{bc}$ & 45.73 \\
\hline HRDBLM-003 & $14.10 \mathrm{c}$ & $15.43 b$ & $14.7 \mathrm{~b}$ & 48.37 & $38.48 \mathrm{c}$ & 43.42 \\
\hline HRDBLM-005 & $29.70 \mathrm{a}$ & $34.53 \mathrm{a}$ & $32.12 \mathrm{a}$ & 51.50 & $42.82 \mathrm{bc}$ & 47.16 \\
\hline HRDBLM-007 & $24.43 \mathrm{ab}$ & $18.47 \mathrm{~b}$ & $21.45 b$ & 52.20 & $48.72 \mathrm{a}$ & 50.46 \\
\hline Marpha Broad Leaf & $20.47 b c$ & $18.55 b$ & $19.51 b$ & 50.80 & $43.45 b$ & 47.13 \\
\hline Khumal Broad Leaf & $19.60 \mathrm{bc}$ & $19.97 b$ & $19.78 b$ & 52.37 & $40.55 b c$ & 46.46 \\
\hline GM & 21.32 & 20.98 & 21.15 & 50.94 & 42.51 & 46.73 \\
\hline CV $(\%)$ & 19.35 & 11.73 & 11.50 & 11.94 & 5.47 & 7.7 \\
\hline F-test & $*$ & $* *$ & $* *$ & NS & $* *$ & NS \\
\hline $\mathrm{CD}(\mathrm{P} \leq 0.05)$ & 7.51 & 4.48 & 4.43 & 11.06 & 4.23 & 6.54 \\
\hline $\mathrm{SEm} \pm$ & 2.38 & 1.42 & 1.41 & 3.51 & 1.34 & 2.08 \\
\hline
\end{tabular}

$\mathrm{SEm} \pm=$ Standard error of mean difference, $\mathrm{CV}=$ Coefficient of variation, $\mathrm{CD}(\mathrm{P} \leq 0.05)=$ Critical difference at 
probability value $0.05, \mathrm{GM}=$ Grand mean, Treatment means followed by common letter (s) within a column are not significantly different at $5 \%$ by DMRT, NS $=$ Non-significant, $*=$ significant at $5 \%, * *=$ significant at $1 \%$, HRDBLM $=$ Horticulture Research Division Broad Leaf Mustard

Number of leaves per plant is directly related to the yield. It is assumed that higher the number of leaves, higher will be the yield if other yield parameters such as leaf length and leaf breadth remain same. The result of the present study are also in agreement with Khatiwada (2008) who reported $43.42 \mathrm{~cm}$ spreading in 'Marpha Broad Leaf' variety under summer season production at Dhankuta.

\section{Length of leaf}

The Length of leaf was highly significant in the first year and significant for the second year. In the first year, statistically the longest leaf was recorded in 'HRDBLM-003' (54.57 cm) and the shortest in 'Khumal Broad Leaf $(31.75 \mathrm{~cm})$. In the second year also, the longest Length of leaf was recorded in 'HRDBLM-003' $(48.56 \mathrm{~cm})$ followed by 'Marpha Broad Leaf' (44.57 $\mathrm{cm})$ and the lowest Length of leaf was observed in 'Khumal Broad Leaf'. The average leaf length of two years was statistically highly significant. The longest leaf length was recorded in 'HRDBLM-003' (51.56 $\mathrm{cm}$ ) followed by 'Marpha Broad Leaf' (43.07 cm) and the shortest length $(35.71 \mathrm{~cm})$ in 'Khumal Broad Leaf' (Table 2).

\section{Breadth of leaf}

The Breadth of leaf was observed non-significant. However; it varied from $17 \mathrm{~cm}$ in 'HRDBLM-005' to $23.57 \mathrm{~cm}$ in 'HRDBLM-001' with the mean $21.33 \mathrm{~cm}$ in the first year. In the second year, the Breadth was statistically the highest in 'Khumal Broad Leaf' (25.13 $\mathrm{cm})$ and it was at par with 'HRDBLM-007' (23.37 cm), 'HRDBLM-003' (23.33 cm) and 'Marpha Broad Leaf' $(22.80 \mathrm{~cm})$. The lowest Breadth of leaf was observed in 'HRDBLM-005' $(17.67 \mathrm{~cm})$. The average data of the two years was statistically highly significant. The maximum Breadth of leaf was recorded in 'Khumal Broad Leaf' $(23.93 \mathrm{~cm}$ ) followed by 'Marpha Broad Leaf' $(22.90 \mathrm{~cm})$ and the lowest $(17.33 \mathrm{~cm})$ being 'HRDBLM-005' (Table 2).

\begin{tabular}{|l|l|l|l|l|l|l|}
\hline \multirow{2}{*}{ Treatments } & \multicolumn{3}{c}{ Table 2. Effect of genotypes on leaf size during 2013 and 2014 at HRS, Dailekh } \\
\cline { 2 - 7 } & \multicolumn{1}{|c|}{$\mathbf{2 0 1 3}$} & \multicolumn{1}{c|}{$\mathbf{2 0 1 4}$} & \multicolumn{1}{c|}{ Average } & \multicolumn{2}{c|}{$\mathbf{2 0 1 3}$} & \multicolumn{2}{c|}{ Le14 } & \multicolumn{1}{c|}{ Average } \\
\hline HRDBLM-001 & $38.74 \mathrm{~b}$ & $41.23 \mathrm{~b}$ & $39.99 \mathrm{~b}$ & 23.57 & $21.07 \mathrm{~b}$ & $22.32 \mathrm{a}$ \\
\hline HRDBLM-003 & $54.57 \mathrm{a}$ & $48.56 \mathrm{a}$ & $51.56 \mathrm{a}$ & 21.40 & $23.33 \mathrm{ab}$ & $22.37 \mathrm{a}$ \\
\hline HRDBLM-005 & $39.17 \mathrm{~b}$ & $42.07 \mathrm{~b}$ & $40.62 \mathrm{~b}$ & 17.00 & $17.67 \mathrm{c}$ & $17.33 \mathrm{~b}$ \\
\hline HRDBLM-007 & $36.71 \mathrm{bc}$ & $43.43 \mathrm{~b}$ & $40.07 \mathrm{~b}$ & 20.29 & $23.37 \mathrm{ab}$ & $21.83 \mathrm{a}$ \\
\hline Marpha Broad Leaf & $41.53 \mathrm{~b}$ & $44.57 \mathrm{ab}$ & $43.07 \mathrm{~b}$ & 23.00 & $22.80 \mathrm{ab}$ & $22.90 \mathrm{a}$ \\
\hline Khumal Broad Leaf & $31.75 \mathrm{c}$ & $39.67 \mathrm{~b}$ & $35.71 \mathrm{~b}$ & 22.73 & $25.13 \mathrm{a}$ & $23.93 \mathrm{a}$ \\
\hline GM & 40.41 & 43.25 & 41.83 & 21.33 & 22.23 & 21.78 \\
\hline CV $(\%)$ & 8.52 & 6.01 & 5.35 & 13.13 & 6.83 & 7.16 \\
\hline F-test & $* *$ & $*$ & $* *$ & $\mathrm{NS}$ & $* *$ & $* *$ \\
\hline CD $(\mathrm{P} \leq 0.05)$ & 6.26 & 4.73 & 4.07 & 5.09 & 2.76 & 2.84 \\
\hline SEm \pm & 1.99 & 1.50 & 1.29 & 1.62 & 0.88 & 0.90 \\
\hline
\end{tabular}

$\mathrm{SEm} \pm=$ Standard error of mean difference, $\mathrm{CV}=$ Coefficient of variation, $\mathrm{CD}(\mathrm{P} \leq 0.05)=$ Critical difference at probability value $0.05, \mathrm{GM}=$ Grand mean, Treatment means followed by common letter (s) within a column are not significantly different at $5 \%$ by DMRT, NS = Non-significant, $*=$ significant at 5\%, ** = significant at 1\%, HRDBLM $=$ Horticulture Research Division Broad Leaf Mustard.

\section{Leaf weight}

The Leaf weight was highly significant in both the years. In the first year, the highest weight $(62.00 \mathrm{~g})$ was recorded in 'HRDBLM-003' followed by 'Marpha Broad Leaf' (57.27g) and 'HRDBLM-007' (53.50g) whereas, the lowest leaf weight (37.00 g) was recorded in 'HRDBLM-001'. Similarly, in the second year, the highest Leaf weight (61.00 g) was observed in 'HRDBLM-003' followed by 'Marpha Broad Leaf' (59.67 g) and 'HRDBLM-007' (49.00 g). In this year, the lowest Leaf weight was observed in 'HRDBLM-005' 
$(36.67 \mathrm{~g})$. The average of the two years data was also statistically highly significant. The highest Leaf weight (61.50 g) was found in 'HRDBLM-003' followed by 'Marpha Broad Leaf' (58.47 g) and the lowest Leaf weight $(37.30 \mathrm{~g})$ was recorded in 'HRDBLM-005' (Table 3).

\section{Leaf yield}

Leaf yield is the most important parameter of Broad Leaf Mustard. Leaf harvesting was started from 30 days of transplanting and continued for 75 days after transplanting in all varieties. The Leaf yield was statistically non-significant in the both years. In the first year, the leaf yield varied from $28.10 \mathrm{mt} / \mathrm{ha}$ in 'HRDBLM-003' to $38.95 \mathrm{mt} / \mathrm{ha}$ in 'HRDBLM-005' where the mean yield of leaf was $34.38 \mathrm{mt} / \mathrm{ha}$. In the second year, the Leaf yield varied from $27.11 \mathrm{mt} / \mathrm{ha}$ in 'HRDBLM-003' to $40.60 \mathrm{mt} / \mathrm{ha}$ in 'HRDBLM-005'. In this year, the mean yield of six genotypes was 33.00 $\mathrm{mt} / \mathrm{ha}$. The average yield of two years revealed that the yield non-significantly differed from $27.60 \mathrm{mt} / \mathrm{ha}$ in 'HRDBLM-003' to $39.78 \mathrm{mt} / \mathrm{ha}$ in 'HRDBLM-005' where the mean yield was $33.69 \mathrm{mt} / \mathrm{ha}$ (Table 3).

\begin{tabular}{|l|c|c|c|c|c|c|}
\hline \multicolumn{3}{|c|}{ Table 3. Effect of genotypes on leaf weight and total leaf yield during 2013 and 2014 at HRS, Dailekh } \\
\hline \multirow{2}{*}{ Treatments } & \multicolumn{3}{c|}{ Leaf weight (g) } & \multicolumn{3}{c|}{ Leaf yield (mt/ha) } \\
\cline { 2 - 7 } & $\mathbf{2 0 1 3}$ & $\mathbf{2 0 1 4}$ & Average & $\mathbf{2 0 1 3}$ & $\mathbf{2 0 1 4}$ & Average \\
\hline HRDBLM-001 & $37.00 \mathrm{~b}$ & $39.00 \mathrm{c}$ & $38.00 \mathrm{c}$ & 33.32 & 31.41 & 32.36 \\
\hline HRDBLM-003 & $62.00 \mathrm{a}$ & $61.00 \mathrm{a}$ & $61.50 \mathrm{a}$ & 28.10 & 27.11 & 27.60 \\
\hline HRDBLM-005 & $37.93 \mathrm{~b}$ & $36.67 \mathrm{c}$ & $37.30 \mathrm{c}$ & 38.95 & 40.60 & 39.78 \\
\hline HRDBLM-007 & $53.50 \mathrm{a}$ & $49.00 \mathrm{~b}$ & $51.25 \mathrm{~b}$ & 38.32 & 31.60 & 34.96 \\
\hline Marpha Broad Leaf & $57.27 \mathrm{a}$ & $59.67 \mathrm{a}$ & $58.47 \mathrm{a}$ & 34.49 & 32.69 & 33.59 \\
\hline Khumal Broad Leaf & $41.50 \mathrm{~b}$ & $48.67 \mathrm{~b}$ & $45.08 \mathrm{~b}$ & 33.10 & 34.60 & 33.85 \\
\hline GM & 48.20 & 49.00 & 48.60 & 34.38 & 33.00 & 33.69 \\
\hline CV (\%) & 10.59 & 6.21 & 7.51 & 27.95 & 13.86 & 16.31 \\
\hline F-test & $* *$ & $* *$ & $* *$ & $\mathrm{NS}$ & $\mathrm{NS}$ & $\mathrm{NS}$ \\
\hline CD $(\mathrm{P} \leq 0.05)$ & 9.29 & 5.538 & 6.64 & 17.48 & 8.32 & 9.99 \\
\hline SEm \pm & 2.95 & 1.76 & 2.11 & 5.55 & 2.64 & 3.17 \\
\hline
\end{tabular}

$\mathrm{SEm} \pm=$ Standard error of mean difference, $\mathrm{CV}=$ Coefficient of variation, $\mathrm{CD}(\mathrm{P} \leq 0.05)=$ Critical difference at probability value $0.05, \mathrm{GM}=$ Grand mean, Treatment means followed by common letter (s) within a column are not significantly different at $5 \%$ by DMRT, NS $=$ Non-significant, $* *=$ significant at $1 \%$, HRDBLM $=$ Horticulture Research Division Broad Leaf Mustard.

The yield of fresh leaf of different genotypes of BLM in present study was higher than the yield of South-East Asian countries. Some earlier report indicated that the yield of BLM varied from 3-21 mt/ha in South-East Asia (Asandhi and Sastrosiswojo, 1988). The study in Philippines reported that the average yield was 11.6 mt/ha during 1986 (Valmayor and Tiamzon, 1988). This revealed that our available varieties are superior to the South-East Asian varieties of BLM. In Nepal, Khatiwada (2008) reported about $31 \mathrm{mt} / \mathrm{ha}$ yield in 'Marpha Broad Leaf' variety of BLM planted at $45 \times 30$ $\mathrm{cm}$ spacing for summer season crop under periodic harvesting at Dhankuta also supported the present study. In another study, Khatiwada etal. (1997) at Pakhribas, Dhankuta, reported that periodic harvesting in BLM could be done up to six months after transplanting. However, in present study, the harvesting of quality leaf was done for two and half months after transplanting.
This may be due to difference in climate and planting season of the studied areas.

\section{Organoleptic test}

Development of scale for organoloptic test which began in 1947 at the quartermaster Food and Container Institute for the Armed Forces was motivated by the need for a rating scale that could overcome the limitations of the cumbersome method of paired comparisons (Peryam, 1950; Peryam and Pilgrim, 1957). Since its development, the 9-point hedonic scale (Peryam and Girardot, 1952; Peryam and Pilgrim, 1957) has been the most commonly used scale for testing consumers' preference and acceptability of foods.

Leaf quality based on the organoleptic test (9-point hedonic scale) was highly significant in both the studied years. During the first year of the study, the 
best quality leaf was observed in 'HRDBLM-001' (9.00) and 'Khumal Broad Leaf'(9.00) followed by 'HRDBLM-007' (8.00). The quality was the lowest in 'HRDBLM-005' (5.00). In the second year of study, leaf quality was the best in 'Khumal Broad Leaf' (8.33) which was statistically at par with 'HRDBLM-001' (7.67) followed by 'HRDBLM-
003 ' and 'HRDBLM-007'(6.67). The average of the leaf quality calculated from two years data revealed that 'Khumal Broad Leaf' got the highest scale (8.67) which was statistically at par with 'HRDBLM-001' (8.33). The lowest score was obtained by 'HRDBLM-005' (Table 4).

\begin{tabular}{|l|c|c|c|}
\hline \multirow{2}{*}{ Table 4. Effect of genotypes on organoleptic test during 2013 and 2014 at HRS, Dailekh } \\
\cline { 2 - 4 } & \multicolumn{2}{c|}{ Organoleptic test (Hedonic scale 1-9) } \\
\cline { 2 - 4 } & $\mathbf{2 0 1 3}$ & $\mathbf{2 0 1 4}$ & Average \\
\hline HRDBLM-001 & $9.00 \mathrm{a}$ & $7.67 \mathrm{ab}$ & $8.33 \mathrm{a}$ \\
\hline HRDBLM-003 & $7.00 \mathrm{c}$ & $6.67 \mathrm{bc}$ & $6.83 \mathrm{bc}$ \\
\hline HRDBLM-005 & $5.00 \mathrm{~d}$ & $5.33 \mathrm{c}$ & $5.17 \mathrm{~d}$ \\
\hline HRDBLM-007 & $8.00 \mathrm{~b}$ & $6.67 \mathrm{bc}$ & $7.33 \mathrm{~b}$ \\
\hline Marpha Broad Leaf & $7.00 \mathrm{c}$ & $6.00 \mathrm{c}$ & $6.50 \mathrm{c}$ \\
\hline Khumal Broad Leaf & $9.00 \mathrm{a}$ & $8.33 \mathrm{a}$ & $8.67 \mathrm{a}$ \\
\hline GM & 7.50 & 6.78 & 7.14 \\
\hline CV $(\%)$ & 9.80 & 10.66 & 5.06 \\
\hline F-test & $* *$ & $* *$ & $* *$ \\
\hline CD $(\mathrm{P} \leq 0.05)$ & 0.18 & 1.13 & 0.66 \\
\hline SEm \pm & 0.06 & 0.42 & 0.21 \\
\hline
\end{tabular}

$\mathrm{SEm} \pm=$ Standard error of mean difference, $\mathrm{CV}=$ Coefficient of variation, $\mathrm{CD}(\mathrm{P} \leq 0.05)=$ Critical difference at probability value $0.05, \mathrm{GM}=$ Grand mean, Treatment means followed by common letter (s) within a column are not significantly different at 5\% by DMRT, ** = significant at $1 \%$, HRDBLM $=$ Horticulture Research Division Broad Leaf Mustard

Note: $1=$ Dislike extremely, $9=$ Like extremely

\section{Conclusion and Recommendation}

Among the six genotypes 'HRDBLM-005' though was found to be higher yielder, with smaller sized leaf and spines on the leaf was not liked by the consumers (5.17 hedonic score). 'HRDBLM-007' was very popular in the mid-hill and the Terai regions of Nepal for several years. The green leaf yield of 'HRDBLM-007' though slightly lower than 'HRDBLM-005',was statistically similar to 'HRDBLM-005', 'HRDBLM-001'. Thus these three genotypes showed superiority among the six tested genotypes and could be recommended for cultivation after testing at farmers' field.

\section{Acknowledgement}

Authors highly acknowledge all the technical staffs of HRS, Dailekh for their continuous effort in completing the trial for the two years.

\section{References}

Asandhi, A.A. and S. Sastrosiswojo, 1988. Research on vegetables in Indonesia. In: AVRDC, 1988a. Vegetable research in South-East Asia. Asian Vegetable Research and Development Center (AVRDC), pp. 95-102. Taiwan: Shanhua, Tainan.

CPDD, 2014. Released and registered crop varieties in Nepal (1960-2013). Nepal: Communication, Publication and Documentation Division, Nepal Agricultural Research Council, Khumaltar, Lalitpur.

Dhillon, S.S. and S. Larsson, 1985. Screening techniques for frost tolerance in Brassica oil seed. Journal of Agricultural Science Cambridge, 104:345-348.

Gomez, K.A. and A.A. Gomez, 1984. Statistical Procedures for Agricultural Research (2nd ed.). USA: John Wiley and Sons, New York.

Khatiwada, P. P., S.R. Gautam, M. P. Thapa, G. Neupane and B. H. Baral, 1997. A review of broad leaf mustard research at PAC (1987-1992) 
PAC UWP No. 8. Nepal: Pakhribas Agricultural Centre, Dhankuta.

Khatiwada, P.P., 2008. Broad Leaf Mustard production during dry season by altering husbandry practices. Nepalese Horticulture, 6 (1): 47-53.

Paudel, M.N., B.K. Joshi and K.H. Ghimire, 2016. Management status of agricultural plant genetic resources in Nepal. Agronomy Journal of Nepal, 4:75-91.

Peryam, D. R. and F.J. Pilgrim, 1957. Hedonic scale method of measuring food preference. Food Technology, 11: 9-1

Peryam, D. R. and N.F. Girardot, 1952. Advanced tastetest method. Food Engineering, 24: 58-61.

Peryam, D. R., 1950. Problem of preference gets GM focus. Food Industries, XXII (12): 42-44.

Valmayor, R.V. and M.F. Tiamzon, 1988. Vegetable production and research policy in the Philippines. In: AVRDC, 1988a. Vegetable research in South-East Asia. Asian Vegetable Research and Development Center (AVRDC), pp.17-30. Taiwan: Shanhua, Tainan. 